\title{
STATISTICAL METHODS \\ FOR FORECASTING THE DEVELOPMENT OF DEMOGRAPHIC INDICATORS IN UKRAINE: APPLICATION CONTEXT
}

\begin{abstract}
The article examines the demographic processes and indicators of Ukraine over the years of its independence. The essence of the concepts "forecast», "forecasting" and "demographic forecast» is considered. It is demonstrated that the results of the demographic forecast and the subsequent strategic analysis constitute essential information for substantiating the prediction of the main parameters of population indicators, future demographic situation and socioeconomic processes in a given area. The conditions for application of demographic forecasting methods are defined. The statistical methods that are most often used in practice to forecast the future population are grouped into methods of extrapolation, methods of shifting ages, methods of statistical modelling (methods of mathematical modelling), methods of expert evaluations. It is determined that in practice each group of statistical methods of demographic forecast-
\end{abstract}

(C) Mykhailo Luchko, Mariia Shesterniak, 2021.

Luchko, Mykhailo, Doctor of Economic Sciences, Professor, Head of the Department of Financial Control and Audit, West Ukrainian National University, Ukraine. ORCID: http://orcid.org/0000-00016499-4188 Email:m.luchko@wunu.edu.ua.

Shesterniak. Mariia, Candidate of Economic Sciences, Associate Professor at Department of Financial Control and Audit, West Ukrainian National University, Ukraine. ORCID: http://orcid.org/00000001-9775-6637 Email: m.shesterniak@wunu.edu.ua. 
ing has its purpose, characterizes a specific demographic phenomenon and is applied to a specific area. Recommendations on using the optimal methods for forecasting and predictive calculations of future demographic indicators of Ukraine are suggested in order to ensure the analytical and predictive component of management.

\section{Key words:}

Demographic forecast; demographic indicators; extrapolation methods; forecast; methods of demographic forecasting; methods of expert evaluations; methods of shifting ages; methods of statistical simulation; methods of statistics; prognostication.

JEL: E20, J11.

4 Figures, 5 Tables, 5 Formulae, 33 References.

\section{Literature Review and Problem Statement}

A key element of the national wealth of any country is the sociodemographic potential formed by many generations of its population. Quantitatively, human potential is formed on the basis of the demography shaped by the state of social development. In today's world, in particular in Ukraine and most EU countries, the phenomenon of depopulation is the biggest challenge to the accumulation of socio-demographic potential. Demographic processes cannot be ignored by the state, as they affect the most important aspects of people's lives and the development of society.

The current stage of socio-economic development of Ukraine is characterized by unfavourable conditions for the development of demographic indicators due to intensified migration and an unstable political situation, temporary annexation of Crimea by a neighbouring country and the armed conflict in the east, significant stratification of society in terms of living standards and economic crisis. These factors led to a decrease in demographic indicators and an increase in the demographic burden. This problem requires significant research and analysis of 
demographic processes that have occurred in Ukraine over the years of independence, the latest changes in the mode of population reproduction, application of predictive calculations of future demographic indicators using the best forecasting methods.

Such scientists as Ye. I. Boiko, A. S. Halchynskyi, V. M. Heyets, F. A. Vazhynskyi, Z. S. Varnalii, S. I. Drohuntsov, S. M. Zlupko, I. V. Kolomiets, M. H. Chumachenko, S. L. Shults and others made a significant contribution to the study of theoretical and applied principles of forecasting in Ukraine. Problematic issues of demographic forecasting are considered by Ukrainian scholars and practitioners, including N. S. Vlasenko, E. M. Libanova, O. V. Makarova, S. I. Pyrozhkov, O. V. Pozniak, L. M. Stelmakh, H. Yu. Shvydka, P. Ye. Shevchuk and others, as well as foreign researchers such as M. Stoto, J. M. Alho and B. D. Spencer, N. Keyfitz, P. Pflaumer and others.

Notably, M. Stoto (1983), J. M. Alho \& B. D. Spencer (1985), N. Keyfitz (1985), P. Pflaumer (1988) consider three main alternative approaches to population forecasts: analysis of errors in the ex-post forecast, time series analysis and expert opinion.

Additionally, some authors prefer a more narrow scope of research. For instance, Timothy Miller (2006) presents three demographic models useful for forecasting demand in the social sector. The first model is a probabilistic national population forecast based on the collective experience of UN member states. It offers a set of probabilistic forecasts as a supplement to the official forecasts of the UN scenario. The second model predicts the population by age and educational level, using a single census. The third model examines the impact of changes in the age structure of the population on the demand of the social sector. Some probable consequences of population aging are considered as an example.

On the other hand, Ewa Tabeau and co-authors (2001) explore models of future mortality trends that are important for population forecasts, health policy, actuarial research, and many other goals.

Meanwhile, Marta Anacka (2017) indicates that the statistical art of population forecasting based on the population model using the cohort-component method, modelling mortality, birth rate and migration using statistical methods based on a theory (demographic, economic, etc.) should include conditions of uncertainty.

Heather Booth (2006) explores three approaches to forecasting demographic processes, namely extrapolation, expectations (birth expectation at the individual level or expert opinion at the population level) and structural modelling based on theory involving exogenous variables. Models include 0-3 factors (age, time and cohort). 

of demographic indicators in Ukraine: application context

Despite the significant number of publications on the topic of the study, some issues require clarification. Therefore, the aim of the paper is to study statistical methods for forecasting demographic indicators of Ukraine.

In accordance with the set aim, the main objectives of the article are to investigate and analyse the demographic processes and demographic indicators of Ukraine over the years of independence; consider the essence of concepts of "forecast», "forecasting" and «demographic forecast»; determine the peculiarities of applying the demographic forecasting methods; group statistical methods of future demographic indicators of Ukraine.

\section{Theoretical and Methodological Prerequisites}

The historical transition of humanity from traditional to more developed societies was accompanied by gradual transformations of demographic processes, which were reflected in the theory of demographic transition. According to this theory, the specifics of population reproduction are largely determined by social processes, as the development of society results in changes associated with increasing life expectancy, reducing mortality in all age groups, the use of birth control. Due to this, the demographic gap between countries with different levels of development is growing. While third world countries still have high birth rates, which are precipitating a «population boom» in the face of increasing life expectancy, most developed regions have now completed the demographic transition and are trying to counter the negative effects of aging (Libanova, 2015). Therefore, the demographic situation is the subject of systematic research of economists, politicians and regular citizens.

Belgian scientist A. Quetelet (1796-1874) is chief among the most influential economists and specialists in various countries who have studied and improved the theory and practice of statistics. He is considered the founder of the theory of statistics. His teachings on averages and statistical patterns are important tools for understanding objective reality. His studies are a testament to the fact that A. Quetelet took an active part in the development of rules for conducting censuses in different countries and, in particular, recommended a ten-year periodicity of their conduct.

Other scholars introduced mathematical methods that had a very positive effect on the development of statistical science, in particular, F. Galton (18221911), K. Pearson (1857-1936), W. Sealy Gosset (1876-1936), R. Fisher (18901962), P. Chebyshev (1821-1894), A. Markov (1856-1922).

With the development of statistics, research related to demographic forecasting has become increasingly relevant, as the population forecast significantly affects the socio-economic processes that occur in certain areas. Therefore, the 
problems of demographic forecasting are highlighted in the works of such foreign demographers as G. Bakhmetov, A. Volkov, W. Isard, E. Cole, F. Lorimer, F. Notestein, etc.

Notably, it is important to understand the essence of such concepts as «forecast», «forecasting» and «demographic forecast».

B. Ye. Hrabovetskyi (2010) interprets «forecast» as a probable, reasoned (based on a system of facts and evidence) judgment about the state of objects (processes, phenomena) in the future or alternative ways and terms of achieving certain results. A forecast should answer two questions: a) what is most likely to happen in the future; $b$ ) how to influence the conditions to achieve the desired goal in the future.

In economic dictionaries, «forecasting» or "prognostication" (Gr. «Prognosis" - prediction, prophecy) is considered as a process of scientific prediction of the future state of various phenomena (Radchenko \& Orlova, 2010). O. M. Volska and N. S. Mykolaichuk argue that «forecasting» is a method that uses both past experience and current assumptions about the future in order to determine it. Existence of forecasts increases the validity of plans, makes it possible to obtain alternative plans (Volska \& Mykolaichuk, 2019). At the same time, «forecasting" is designed to perform a two-pronged task: on the one hand, to paint a picture of both the near and distant future based on the past and present, and on the other hand, to develop the basics of today's activities based on scientific prediction. The plan, based on forecast data, is future-oriented (Hrabovetskyi, 2010).

According to domestic scientists, the "demographic forecast» is a scientifically sound prediction of the future demographic situation and the main parameters of population trends, namely number, sex, age and family structure, birth rate, mortality, migration. This is the basis for further forecasts and plans of socio-economic processes in general (prospects for production and consumption of goods and services, housing, social infrastructure development, health and education, pension system, etc.) (Vlasenko et al., 2006). Thus, the demographic forecast is a predictive calculation of the population (calculation of the number and sex-age structure, based on data on changes in demographic characteristics).

It should be borne in mind that the indicators of demographic forecasting are calculated for specific timeframes, including short-term (covering a period of up to 5 years), medium-term (term of 20-30 years), and long-term (covering time that may exceed a century). As practice shows, short-term forecasts are the most accurate and they are needed to achieve the immediate goals of economic development. Medium-term forecasts are less accurate, but quite reliable, can determine the future population of the country. In turn, long-term forecasts are not as sound as the others, but they are essential for scientific predictions. 

of demographic indicators in Ukraine: application context

Statistics studies social phenomena and processes from the quantitative point of view using specific methods. The main methods of statistics include the method of mass observations (the law of large numbers), grouping method, method of generalizing indicators, and method of qualitative analysis.

With this in mind, V. Zakhozhai and V. Fedorchenko (2006) argue that "statistical methods» are a set of general and special, unique to statistics methods and research approaches.

Various indicators are determined using statistical methods. For example, forecasting methods are used to study demographic processes in a particular area. Studies show that in the modern period, scientists estimate more than 200 different forecasting methods. However, as practice shows, 15-20 methods are used most often. Methods of demographic forecasting allow us to determine demographic indicators and make long-term calculations of the future population.

The main demographic indicators include: total population; total population growth; natural population growth; number of births (persons); number of deaths (persons); number of dead children under 1 year; migration balance («net migration»); share of women of reproductive age; average life expectancy; etc. At the same time, the important generalizing demographic coefficients include the birth rate, mortality rate, infant mortality rate, marriage rate, divorce rate, and others.

\section{Analysis of the Trends and Structure of Ukraine's Population in 1991-2020}

Ukraine's demographics have changed significantly since independence. According to the State Statistics Service of Ukraine, Ukraine has lost $20 \%$ of its citizens in the 29 years of independence. Studies show that this is partly due to the annexation of the Autonomous Republic of Crimea by a neighbouring state and military action in the east of the country, however, the main reason for population decline since independence is that millions of Ukrainians have left the country in search of work and higher earnings. In particular, in 1990 the population of Ukraine was 51.838 million people, during the first years of independence (namely, until 1995) the population decreased by only 110 thousand people, then the country began to lose 2.2-2.3 million people every 5 years. In 2017, the population of Ukraine was 42.585 million people (i.e., the population decreased by 9.253 million over 27 years). In 2019, the population of Ukraine was 42.153 million people (Table 1).

According to the State Statistics Service of Ukraine, as of November 1, 2020, the population of Ukraine is 41.671 million people. The change in the population of Ukraine is also illustrated by the graph below (Fig. 1). 
Table 1

Total population of Ukraine in 1990-2020

\begin{tabular}{|c|c|}
\hline Year & Population, million people \\
\hline 1990 & 51,838 \\
\hline 1991 & 51,944 \\
\hline 1993 & 52,244 \\
\hline 1995 & 51,728 \\
\hline 1997 & 50,818 \\
\hline 1999 & 49,918 \\
\hline 2000 & 49,430 \\
\hline 2001 & 48,923 \\
\hline 2003 & 48,003 \\
\hline 2005 & 47,280 \\
\hline 2007 & 46,646 \\
\hline 2009 & 46,143 \\
\hline 2010 & 45,963 \\
\hline 2011 & 45,778 \\
\hline 2012 & 45,633 \\
\hline 2013 & 45,553 \\
\hline $2014 *$ & 45,426 \\
\hline 2015 & 42,929 \\
\hline 2016 & 42,760 \\
\hline 2017 & 42,585 \\
\hline 2018 & 42,386 \\
\hline 2019 & 42,153 \\
\hline 2020 & 41,902 \\
\hline
\end{tabular}

*Note: since 2014, the population statistics exclude the occupied territories (Crimea, Sevastopol, part of Donbass)

As Figure 1 shows, there is an absolute reduction in the population of Ukraine. Demographers have been warning about this problem for a long time, since in 1991 the number of deaths in Ukraine exceeded the number of newborns. Admittedly, two years later, in 1993, due to migration processes (many Ukrainians returned to live in their homeland), the population of Ukraine increased to its maximum of 52.244 million. However, as of January 1, 2019, the population of Ukraine is $\mathbf{4 2 . 1 5 3}$ million, meaning Ukraine has lost 10 million people. 
Figure 1

Changes in the population of Ukraine in 1990-2020

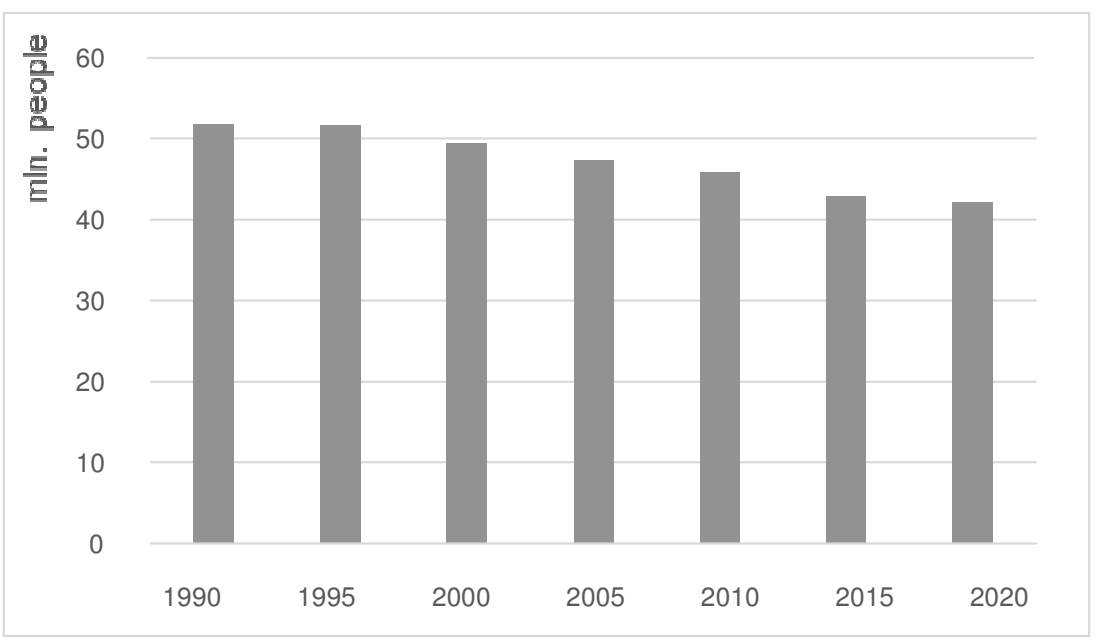

*Note: since 2014, the population statistics exclude the occupied territories (Crimea, Sevastopol, part of Donbass)

Source: Designed by the authors using the data of State Statistics Service of Ukraine (n.d.) and Ministry of Finance of Ukraine (n.d.).

Notably, the population in the age category «60+» has not changed over the years of Ukraine's independence. At the same time, the number of children and persons aged 16-59 has decreased significantly: number of children has decreased by 5 million (now at 6.887 million), while there are 4.3 million less adults (now under 26 million people) (Table 2).

As Table 2 shows, population aging is occurring in Ukraine both due to the growing number of elderly people and due to low birth rates.

In 2017, the American company Bloomberg, which is one of the world's leading providers of financial information, investigated the problem of high demographic burden (Fig. 2), while showing the number of employees in different countries per retiree.

As Figure 2 shows, Ukraine is among the countries with a high aging index (population aging index - the ratio of the number of people working to retirees). The ten countries with the highest aging index included France (2.2), Singapore (2.2), Malta (2.3), Sri Lanka (2.3), Belarus (2.3), Japan (2.3), Russia (2.4), Greece (2.5), Thailand (2.6) and Bulgaria (2.6). It should be noted that the retirement age in 178 countries was taken into account. 
Table 2

Age distribution of the population of Ukraine, million persons

\begin{tabular}{|c|c|c|c|}
\hline Year & $0-15$ y.o. & $16-59$ y.o. & $60+$ \\
\hline 1990 & 11,814 & 30,291 & 9,451 \\
\hline 2000 & 9,572 & 29,353 & 10,190 \\
\hline 2010 & 6,983 & 29,329 & 9,471 \\
\hline 2015 & 6,816 & 26,613 & 9,330 \\
\hline 2016 & 6,856 & 26,317 & 9,417 \\
\hline 2017 & 6,887 & 25,982 & 9,546 \\
\hline 2018 & 6,896 & 25,641 & 9,680 \\
\hline 2019 & 6,863 & 25,294 & 9,827 \\
\hline 2020 & 6,787 & 24,968 & 9,978 \\
\hline
\end{tabular}

Source: Compiled by the authors using the data of Radchenko \& Orlova (2010) and State Statistics Service of Ukraine (n.d.).

According to the State Statistics Service of Ukraine, the birth rate in the country has been gradually declining since 2013 . The sharpest decline was recorded in 2015. While there were 396.9 thousand newborns in 2014, the indicator in 2015 was 348.1 thousand.

Studies show that the decrease in the share of young people has a negative impact on the demographic structure of the population, localizing the prospects for the reproduction of generations as a major driver of progress. Under such conditions, the problem of high demographic burden becomes especially relevant, when small contingents of the employed population are forced to fill the revenue side of the budget of Ukraine, which, in turn, depends on the labour force, while the number of people incapable of work increases. Estimation and planning of the state budget necessitate macroeconomic forecasting. The accuracy of determining the number, gender and age composition of the population plays an important role, as these data are the basis for determining the country's revenues and expenditures in the future, in particular, contributions to pensions, social benefits, funding of educational and medical institutions, etc. As a result, the pressure on taxpayers increases and the extent of social guarantees diminishes due to the lack of resources of insurance systems and budgets of different levels. Therefore, according to foreign practice, the countries of North-Western Europe pursue an active policy of stimulating the birth rate, as well as adaptation of the population and all social institutions to the population aging. 
Figure 2

\section{Countries at risk of population aging}

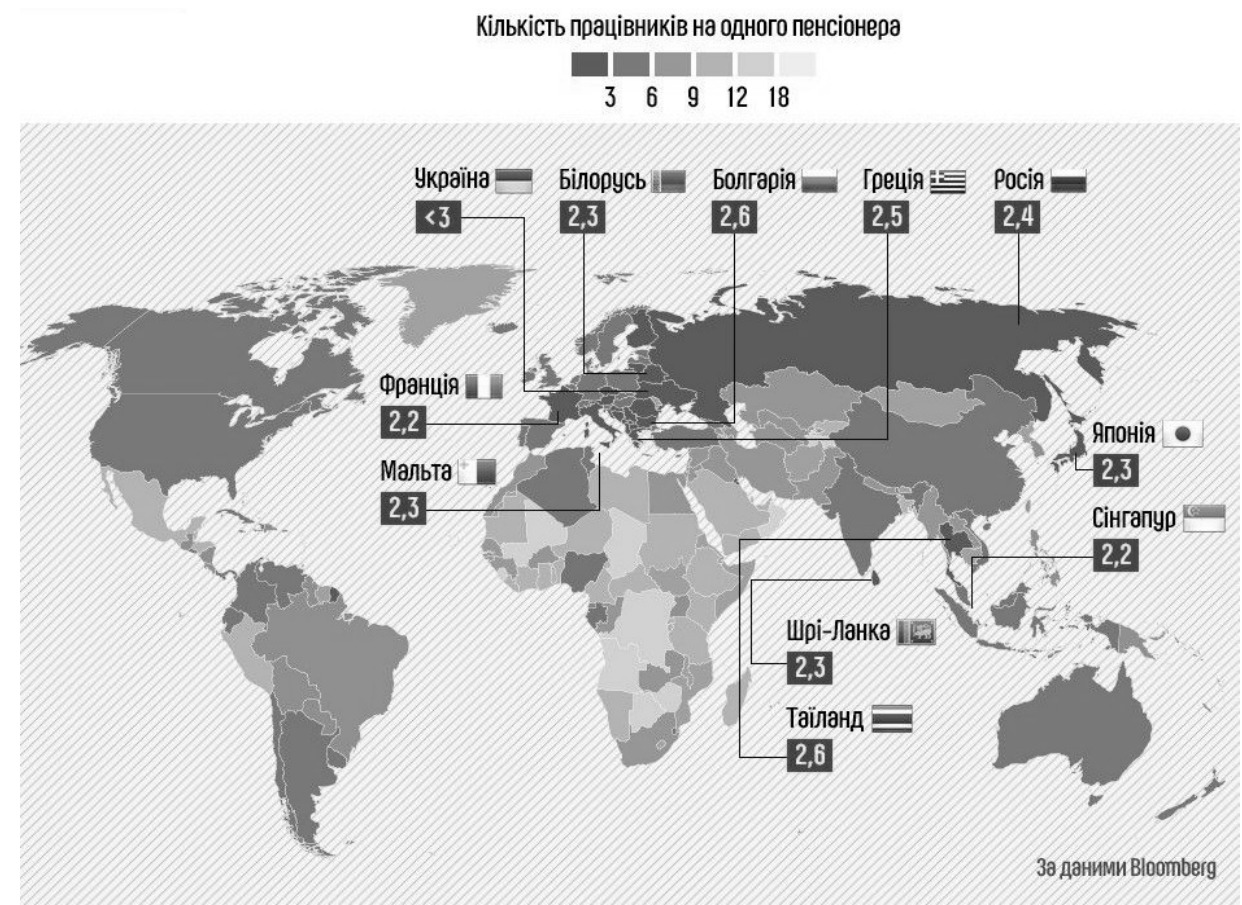

Source: TSN. (2017, February 1). Bloomberg named the countries most at risk of aging. Infographics [in Ukrainian]. https://tsn.ua/svit/starinnya-vdarit-po-rf-ta-bilorusi-ukrayinablizka-do-mezhi-infografika-873468.html

Summarizing the above, it should be noted that comprehensive demographic substantiations will help determine the size of the state budget revenues, which depend on the size of the workforce, education, skills and level of economic activity.

Statistics show that 630 thousand babies were born in Ukraine in 1991, but, for example, in 2015 there were only 411 thousand newborns (State Statistics Service of Ukraine). However, the relative birth rates in the country do not differ much. Thus, while in 1991 for every thousand Ukrainians 12 babies were born, in 2015 the indicator equalled 10.7. The lowest birth rates were recorded in 1999-2002, when less than 400,000 babies were born in Ukraine. The lowest birth rate per thousand people was recorded in 2001 - only 7.7. As for mortality 
rates, 669 thousand people died in Ukraine in 1991 and 594 thousand - in 2015. The number of deaths among Ukrainians was highest in 1999-2009, when more than 700,000 people died each year, for example, in 2005 this figure was at 782,000 . However, the death rate in 2010 was 698 thousand people, and in 2019 - 581 thousand.

According to studies, natural population growth during all the years of independence was negative and on average ranged from 4-7 people per 1 thousand people (Table 3).

Table 3

Dynamics of population growth in Ukraine

\begin{tabular}{|c|c|c|c|}
\hline Year & Birth rate & Mortality rate & $\begin{array}{c}\text { Natural growth } \\
\text { rate }\end{array}$ \\
\hline 1990 & 12,6 & 12,1 & 0,5 \\
\hline 1995 & 9,6 & 15,4 & $-5,8$ \\
\hline 2000 & 7,8 & 15,4 & $-7,6$ \\
\hline 2005 & 9,0 & 16,6 & $-7,6$ \\
\hline 2010 & 10,8 & 15,2 & $-4,4$ \\
\hline 2015 & 10,7 & 14,9 & $-4,2$ \\
\hline 2016 & 10,3 & 14,7 & $-4,4$ \\
\hline 2017 & 9,4 & 14,5 & $-5,1$ \\
\hline 2018 & 8,7 & 14,8 & $-6,1$ \\
\hline 2019 & 8,1 & 14,7 & $-6,6$ \\
\hline
\end{tabular}

Note: per 1000 people.

As Table 3 shows, the excess of mortality rate over birth rate decreases natural population growth, which, in turn, leads to a reduction in the overall life expectancy of the country and a sharp shift in the demographic structure towards aging. These indicators make it clear that a modern Ukrainian family socializes (gets an education, a profession, looks for a job, gets a job) first, and only then gives birth to a child, as is the case in many European countries.

One of the positive demographic indicators in Ukraine is the increasing average life expectancy (Table 4). For example, in 2016, this figure for Ukrainian citizens was 71.68 years (66.73 for men and 76.46 for women). Note that the average life expectancy at birth is calculated from the mortality rates for each age, starting from birth. 
Table 4

Average life expectancy in Ukraine, years

\begin{tabular}{|c|c|c|c|}
\hline Year & Both genders & Men & Women \\
\hline 1990 & 70,42 & 65,60 & 74,82 \\
\hline 1995 & 66,79 & 61,22 & 72,54 \\
\hline 2000 & 67,72 & 62,10 & 73,53 \\
\hline 2005 & 67,96 & 62,23 & 73,97 \\
\hline 2010 & 70,44 & 65,28 & 75,50 \\
\hline 2015 & 71,38 & 66,37 & 76,25 \\
\hline 2016 & 71,68 & 66,73 & 76,46 \\
\hline 2017 & 71,98 & 67,02 & 76,78 \\
\hline 2018 & 71,76 & 66,69 & 76,72 \\
\hline 2019 & 72,01 & 66,92 & 76,98 \\
\hline
\end{tabular}

As Table 4 shows, over the last 29 years, the average life expectancy at birth was the highest in 2019 (72.01 years), and the lowest in 1995 (66.79 years).

\section{Impact of Migration \\ on the Demographic Indicators of Ukraine}

The impact of migration has significantly increased once Ukraine gained its independence, which is due to both the collapse of a single state and the new opportunities for free movement of population within and outside the country. This was exacerbated by the negative values of natural population growth associated with the influence of economic and socio-psychological factors - a sharp decline in the birth rate to the lowest level in the world (in 2002), an increase in mortality of working age population and stagnation of indicators on the elderly (Vlasenko et al., 2006).

Our research shows that the decline in the population of Ukraine over the years of independence, declining birth rates, aging population, the mortality rates exceeding birth rates and declining natural population growth have become the characteristic features of the latest demographic trends. Moreover, the composition of the population was negatively affected by migration processes. Largescale temporary outflow of population affects the birth rate. As practice shows, Ukrainian labour migrants in European countries increasingly acquire the status of «permanent resident» and remain to live there. 
According to UN estimates, the number of international migrants worldwide was almost 258 million (or 3.4\% of the world's population) in 2017 (Migration Policy Institute, n.d.). Figure 3 presents a map of immigrants and emigrants by country of origin and destination.

Figure 3

Total immigrant and emigrant population by country, mid-2017 estimates

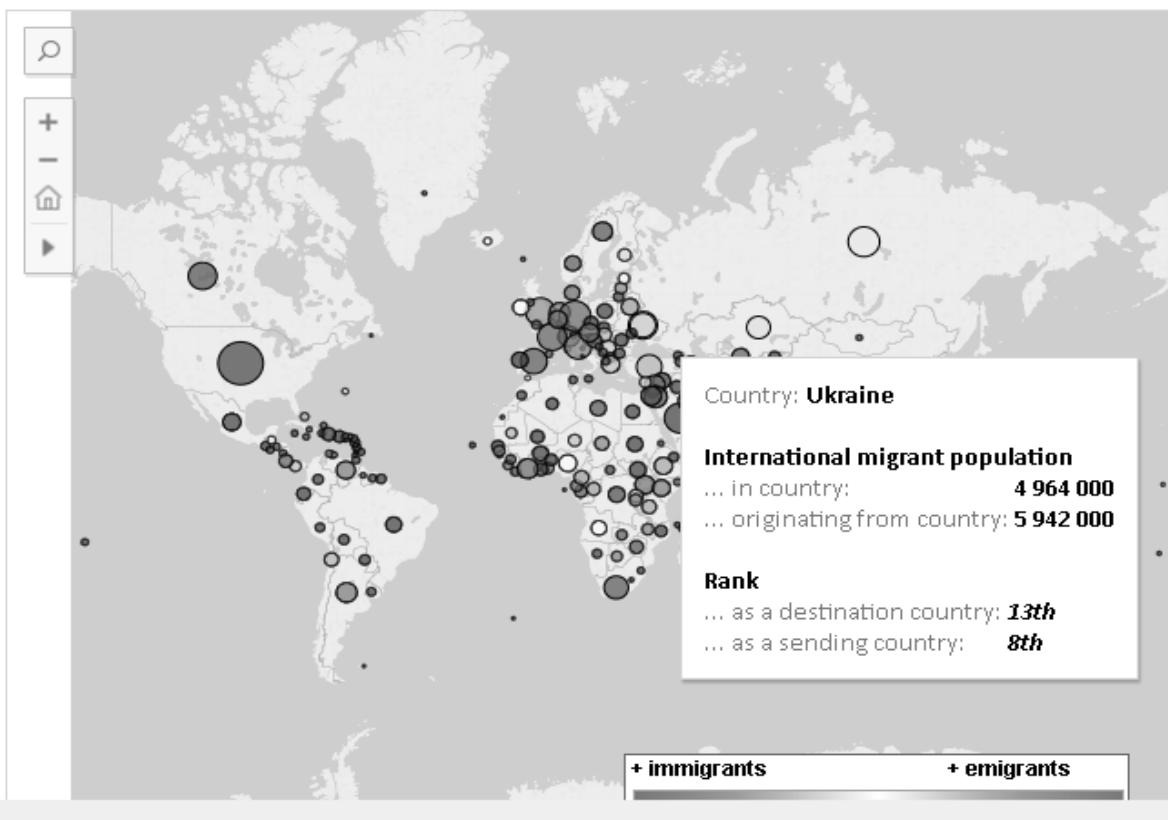

Source: Migration Policy Institute. (n.d.). Immigrant and Emigrant Populations by Country of Origin and Destination [Interactive map]. Retrieved from https://www.migrationpolicy.org/ programs/data-hub/charts/immigrant-and-emigrant-populations-country-origin-and-destination

According to the State Statistics Service of Ukraine for 2015-2017, the number of labour migrants reached 1.303 million. The share of labour migrants in the total population was $4.5 \%$. Compared to $2010-2012$, this figure increased by almost $10 \%$. The main countries for the «import» of Ukrainian labour are Poland (38.9\%), the Russian Federation (26.3\%), Italy (11.3\%) and the Czech Republic $(9.4 \%)$. According to studies, out of people who leave the country, most have vo- 
cational education (33.9\%) or complete general secondary education $(30.1 \%)$, and only $16.4 \%$ have complete higher education.

Information on migration provided by the State Statistics Service of Ukraine indicates that, for example in 2004, 38,567 persons arrived and 46,182 persons left the country, meaning the migration balance was -7615 persons. Meanwhile, in 2018 39,307 people arrived and 24,252 people left (migration balance was 15055 people). In 2019, the indicators increased further - 45011 people arrived and 26789 people left (migration balance was 18222 people).

Our research shows that major changes in the labour market and migration processes are not expected in the near future. The number of labour migrants of Ukraine will depend on economic (mainly wages and purchasing power of hryvnia) and non-economic factors (social, cultural, humanitarian, etc.). Thus, the financial stability of citizens, their needs, and employment policies of neighbouring countries will become significant.

\section{Medium-Term Forecasting of Demographic Indicators of Ukraine}

The demographic forecasts are important for shaping the long-term and medium-term strategy of socio-economic development of Ukraine. Comprehensive demographic substantiations and modern methodology of demographic forecasting will have a significant impact on the results of the interval forecast of the population of Ukraine.

The methodology of demographic forecasting includes both theoretical validity and particularity of methods and techniques of predictive calculations of the future population. The methods of demographic forecasting include methods of extrapolation, methods of shifting ages, methods of statistical modelling and methods of expert evaluation, which are described by the authors in Table 5.

As Table 5 shows, the authors have identified four groups of methods for demographic forecasting. The first two groups of forecast methods, extrapolation methods and methods of shifting ages, are the most common. Their main area of application is forecasting the population of small areas. In addition, these methods should be used in areas with unreliable demographic statistics. The authors' research has shown that demographers are abandoning "extrapolation methods» in favour of the widespread "methods of shifting ages», which are based on census data, age-specific mortality rates and birth rates. Note that in contrast to the «methods of extrapolation», which were relevant in the era of long-term planning, «methods of shifting ages» make it possible to obtain not only the total population, but also its distribution by sex and age. 
Table 5

Methods of demographic forecasting

\begin{tabular}{|c|c|}
\hline $\begin{array}{l}\text { FORECASTING } \\
\text { METHODS }\end{array}$ & $\begin{array}{c}\text { ESSENCE OF THE METHOD } \\
\text { AND RECOMMENDATIONS FOR APPLICATION }\end{array}$ \\
\hline $\begin{array}{l}\text { Extrapolation } \\
\text { methods }\end{array}$ & $\begin{array}{l}\text { The use of «extrapolation methods» to estimate the future } \\
\text { population is based on the assumption that the identified } \\
\text { trends in births, deaths and migration will remain stable over } \\
\text { the forecast period. } \\
\text { Using the method of extrapolation, we can get the most accu- } \\
\text { rate estimate of the future population by summarising indica- } \\
\text { tors of the dynamics: } \\
\text { 1) extrapolation based on the average absolute growth rate: } \\
S_{t}=S_{0} \cdot \bar{x}^{t} \text {, } \\
\text { where } \bar{x}^{t}-\text { indicator of average absolute population growth; } \\
S_{t}-\text { projected population in year } t \text {; } \\
S_{0}-\text { population at the beginning of the forecast period; } \\
t-\text { forecast period; } \\
\text { 2) extrapolation based on the average growth rate: } \\
S_{t}=S_{0} \cdot\left(1+\bar{x}_{n p}\right)^{t} \text {, } \\
\text { where } \bar{x}_{n p}-\text { average absolute population growth rate; } \\
\text { 3) extrapolation based on the average growth rate: } \\
S_{x}^{t}=S_{x-1}^{t-1} . P_{x-1} \text {, } \\
\text { where } P_{x-1}-\text { indicator of average population growth rate. }\end{array}$ \\
\hline $\begin{array}{l}\text { Methods } \\
\text { of shifting ages }\end{array}$ & $\begin{array}{l}\text { «Methods of shifting ages» are the methods for calculating } \\
\text { the future gender and age structure of the population. These } \\
\text { methods are based on the use of data on age and survival } \\
\text { rates from mortality tables. } \\
\text { The essence of «methods of shifting ages» is that the popula- } \\
\text { tion of the age group } x \text { at the time } t \text { is calculated as the prod- } \\
\text { uct of the population of the age group }(x-[1]) \text { at the time }(t-1) \\
\text { and the survival rate for a given age group, which shows what } \\
\text { proportion of people aged }(x-1) \text { will live to be } x \text { years old. } \\
\text { If the age composition of the population is known on a certain } \\
\text { date, it is possible to calculate the estimated population at } \\
\text { each age in a year, two years, etc. (without taking migration } \\
\text { into account). } \\
\text { Data on the age composition of women aged } 15-49 \text { and spe- } \\
\text { cial fertility rates are used to determine the possible number } \\
\text { of births: }\end{array}$ \\
\hline
\end{tabular}



of demographic indicators in Ukraine: application context

\begin{tabular}{|c|c|}
\hline $\begin{array}{l}\text { FORECASTING } \\
\text { METHODS }\end{array}$ & $\begin{array}{c}\text { ESSENCE OF THE METHOD } \\
\text { AND RECOMMENDATIONS FOR APPLICATION }\end{array}$ \\
\hline & $\begin{array}{l}P^{t}=\sum_{x=15}^{49} K p_{\text {спец. } x} \times \bar{S}_{x}^{t} \\
\text { where } K_{P} \text { спец. } x-\text { special fertility rate for women aged } x \\
\bar{S}_{x}^{t}-\text { average number of women aged } x \\
S_{t}=S_{0}\left(1+\frac{K \text { з.приростy }}{1000}\right)^{t} \\
K_{3 . \text { приросту }} \text { - total growth rate. }\end{array}$ \\
\hline $\begin{array}{l}\text { Methods } \\
\text { of statistical } \\
\text { modelling } \\
\text { (methods } \\
\text { of mathematical } \\
\text { modelling) }\end{array}$ & $\begin{array}{l}\text { The essence of «statistical modelling methods" is to use re- } \\
\text { gression models that characterize the dependence of demo- } \\
\text { graphic phenomena on selected factors for demographic } \\
\text { forecasting. } \\
\text { Note that methods of mathematical modelling constitute a } \\
\text { separate group, as they use models based on the use of } \\
\text { mathematical functions (e.g. parabola, exponential curve, } \\
\text { etc.). } \\
\text { If the population is known at the beginning of a period, then } \\
\text { the prospective population in } t \text { years can be determined on } \\
\text { the basis of the exponential law of population growth using } \\
\text { the formula: } \\
\text { K3.npupocmy }=\frac{(P-y)+(\Pi-B)}{\bar{S}} \cdot 1000 \% \text {, } \\
\text { where (P-y) - natural population growth; } \\
\text { ( } \bar{S}-B)- \text { migration balance; } \\
t-\text { forecase annual population; } \\
\text { Regression models are used when the assessment should be } \\
\text { made in accordance with the expected or known changes } \\
\text { (which are considered factor features) of the values of certain } \\
\text { economic or social factors. } \\
\text { Modern means of information processing make it possible to } \\
\text { enter a large number of factors into the analysis. In this case, } \\
\text { correlation-regression models reveal the qualitative nature of } \\
\text { demographic phenomena and the relationship of factors that } \\
\text { shape their intensity. That is, this type of population forecasts } \\
\text { is based on the construction of multidimensional regression } \\
\text { models built on the results of multiple correlation and regres- } \\
\text { sion analysis. It should be used for regional forecasting. }\end{array}$ \\
\hline $\begin{array}{l}\text { Methods } \\
\text { of expert } \\
\text { evaluations }\end{array}$ & $\begin{array}{l}\text { «Expert evaluation methods» or «expertise methods» are } \\
\text { based on the assumption that the opinions of specialists in a } \\
\text { particular field of knowledge can be used build an adequate }\end{array}$ \\
\hline
\end{tabular}




\begin{tabular}{|c|c|}
\hline $\begin{array}{l}\text { FORECASTING } \\
\text { METHODS }\end{array}$ & $\begin{array}{c}\text { ESSENCE OF THE METHOD } \\
\text { AND RECOMMENDATIONS FOR APPLICATION }\end{array}$ \\
\hline & $\begin{array}{l}\text { representation of future development, taking into account all } \\
\text { possible shifts and leaps. The essence of the «method of ex- } \\
\text { pert evaluations» is the processing of information obtained } \\
\text { from experts. } \\
\text { Methods based on the use of expert evaluations are divided } \\
\text { into two groups: 1) individual (personal) expert assessments; } \\
\text { 2) group (collective) expert assessments. } \\
\text { There are two methods of individual expert evaluation: inter- } \\
\text { views and analytical notes. } \\
\text { Methods of group expert evaluations are based on the princi- } \\
\text { ples of identifying the collective opinion of experts for the } \\
\text { long-term development of the forecast. Collective methods of } \\
\text { expert evaluation include, first of all, the panel method and } \\
\text { the Delphi method. }\end{array}$ \\
\hline
\end{tabular}

As for the methods of statistical modelling (methods of mathematical modelling), practice shows that they are used for demographic forecasting of regression models that characterize the dependence of demographic phenomena on selected factors. In particular, regression models should be used in regional forecasting.

The use of expert evaluation methods, which are quite numerous and diverse, requires the demographer to be experienced in the field for which the forecast is developed. The qualified specialist should be the one to choose which expert evaluation will be used, whether the individual (interviews or analytical notes) or group (panel method, Foresight method, Delphi method, etc.) approach is best.

Our research shows that in the modern forecasting methodology, Foresight technology is used as a tool for innovative organization of society and predicting future. This technology combines the best of forecasting and strategic planning. Foresight has only recently been introduced in Ukraine, but is rapidly gaining momentum and popularity. Note that the Delphi method is the basis for Foresight method. Studies show that the modern world contributes to the development and improvement of expert forecasting methods, which in turn narrow the possibility of inaccurate calculations.

Ptoukha Institute for Demography and Social Studies of the National Academy of Sciences of Ukraine has developed a forecast of the number and age of Ukrainians for 2013-2061 (Fig. 4). This institute has been forecasting the main demographic indicators of Ukraine since 2006. In 2011, the population of 
Ukraine was recalculated according to the average version of the forecast. According to calculations, the population in 2020 should be 44.302 million people (the real figure is 41.902 according to the State Statistics Service of Ukraine); by 2050 the population should decrease to 39.195 million people, and by 2060 it should be 37.147 million people.

\section{Figure 4}

Forecast of the number and age of the population of Ukraine for 2013-2061

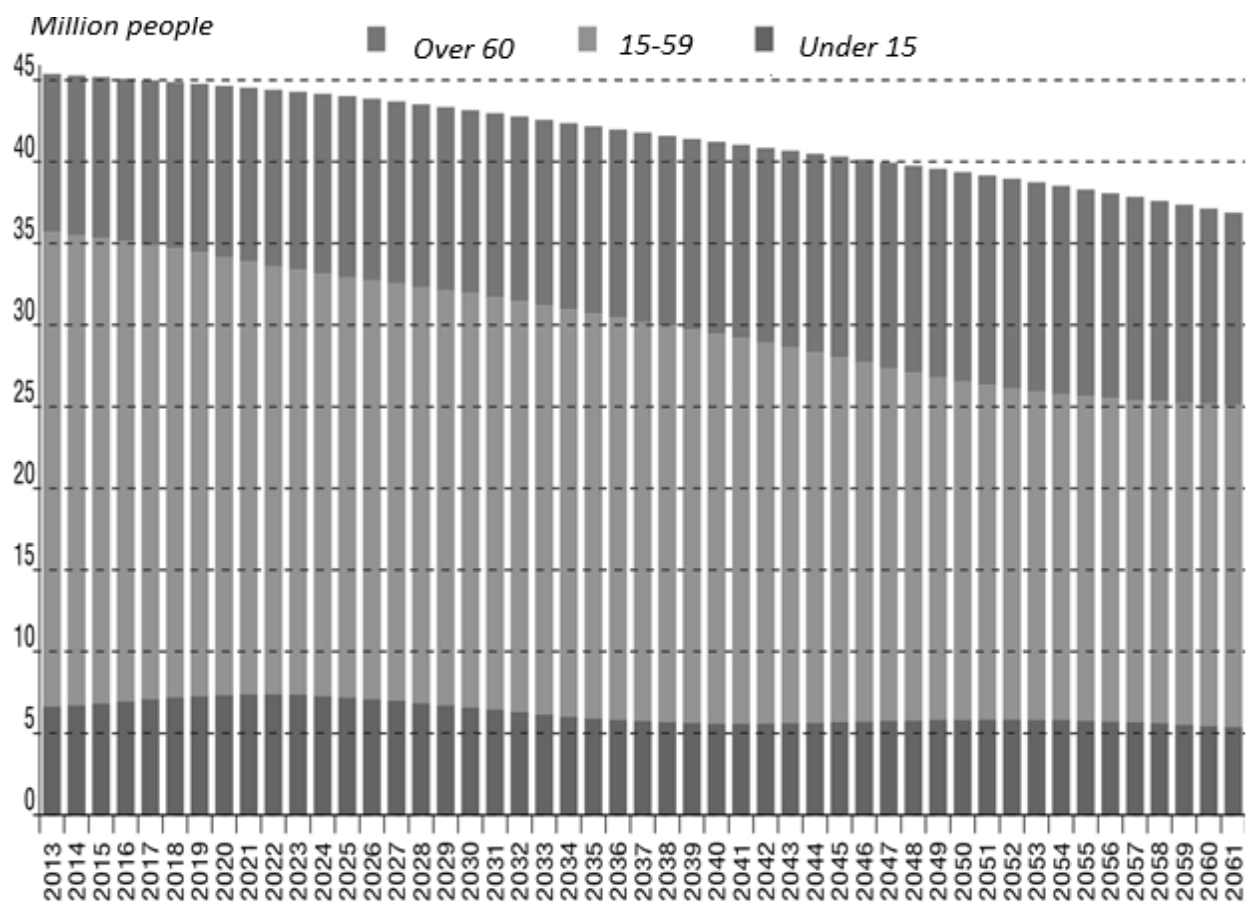

Source: Uriadovyi Kuriier. (2013, December 20). Forecast of the number and age of the population of Ukraine [in Ukrainian]. https://ukurier.gov.ua/uk/articles/prognoz-chiselnostita-vikovogo-skladu-naselennya

In the $21^{\text {st }}$ century, special computer programs have been developed that make it possible to predict population dynamics using various analytical functions. As practice shows, domestic and European demographers use standard spreadsheet software for demographic forecasting. 


\section{Conclusions}

Thus, research and analysis of demographic processes that occurred in Ukraine over the years of independence, allows us to draw several conclusions.

First, Ukraine has lost $20 \%$ of its population (10 million people) in 29 years of independence. Due to the growing number of elderly people, the population is aging. The birth rate is low (natural population growth is 4-7 babies per 1 thousand people). Life expectancy is increasing (it was 72.01 years in 2019). The influence of migration processes is growing. The demographic burden is high. There is a need to return labour migrants to Ukraine.

Second, the results of the demographic forecast and the subsequent strategic analysis constitute essential information for substantiating the prediction of the main parameters of population indicators, future demographic situation and socio-economic processes in a given area.

Third, in modern times, demographers often use methods of demographic forecasting, which can be grouped into methods of extrapolation, methods of shifting ages, methods of statistical modelling (methods of mathematical modelling), methods of expert evaluations.

Fourth, in practice, each group of statistical methods of demographic forecasting has its purpose, characterizes a specific demographic phenomenon and is applied to a specific area.

Fifth, methods of expert evaluations are increasingly being used in order to ensure the analytical and predictive component of management and to develop a development strategy. The more complex the studied problem, the greater the need to rely on the qualitative assessment of experts, who use intuitive and logical analysis. In view of this, the study of statistical forecasting methods gives the authors reason to recommend the use of expert evaluation methods (a number of certain techniques and methods) for the calculation of future demographic indicators of Ukraine.

Prospects for further research in this area are associated with the creation of practical methodological recommendations for the application of expert evaluation methods of demographic forecasting. 


\section{References}

Alho, J. M., \& Spencer, B. D. (1985). Uncertain population forecasting. Journal of the American Statistical Association, 80(390), 306-314.

Anacka, M. (2017). Modelling and forecasting of demographic phenomena. JRCSAS-INGSA Summer School. https://ec.europa.eu/jrc/communities/sites/ jrccties/files/3_modelling_forecasting.pdf

Beshelev, S. D., \& Gurvich, F. G. (1980). Mathematical and statistical methods of expert valuations (2nd ed.) [in Russian]. Statistika.

Booth, H. (2006). Demographic forecasting: 1980 to 2005 in review. International Journal of Forecasting, 22(3), 547-581. URL: https://doi.org/10.1016/ j.ijforecast.2006.04.001

Drukach, O. (2017, August 21). Minus 10 million: How the demographic structure of Ukraine was changing over the course of independence [in Ukrainian]. Kanal 24. https://24tv.ua/minus_10_milyoniv_yak_zminyuvalas_demografichna_struktura_ukrayini_za_chasi_nezalezhnosti_n855191

Duliuk, I. V., \& Matusov, Yu. P. (2010). Modeling of demographic processes in Ukraine using optimal recognition procedures [in Ukrainian]. Ekonomichnyi Visnyk NTUU "KPl", 7, 250-255. http://economy.kpi.ua/uk/taxonomy/ term/749

Ermilov, A. P. (1987). Macroeconomic forecasting in the USA [in Russian]. Nauka.

Hnatiienko, H. M., \& Snytiuk, V. Ye. (2008). Expert technologies of decisionmaking: monograph [in Ukrainian]. McLaut.

Hrabovetskyi, B. Ye. (2010). Methods of expert assessments: Theory, methodology, areas of use: monograph [in Ukrainian]. VNTU.

Keyfitz, N. (1985). A probability representation of future population. Zeitschrift für Bevölkerungswissenschaft, 11(2), 179-191.

Kildishev, G. S., Kozlova, L. L., \& Ananieva, S. P. (1990). Population statistics with the basics of demography: textbook [in Russian]. Finansy i Statistika.

Law of Ukraine "On state forecasting and development of programs of economic and social development of Ukraine" of December 2, 2012 [in Ukrainian]. https://zakon.rada.gov.ua/laws/show/ru/1602-14.

Libanova, E. M. (2007). Human development in regions of Ukraine: Analysis and forecast [in Ukrainian]. Ptoukha Institute for Demography and Social Studies of the National Academy of Sciences of Ukraine. 
Libanova, E. M. (Ed.). (2015). Human development in Ukraine. Modernization of social policy: Regional Aspect (collective monograph) [in Ukrainian]. Ptoukha Institute for Demography and Social Studies of the National Academy of Sciences of Ukraine.

Luchko, M. R. (2017). Economy of Ukraine: The analysis of the innovative way of the development. Economics, Management and Sustainability, 2(2), 95103. https://doi.org/10.14254/jems.2017.2-2.10

Luchko, M. R., Arzamasova, O., \& Vovk, I. (2019). Personnel potential of national economy and gross domestic product: The case of Ukraine. Montenegrin Journal of Economics, 15(2), 59-70.

Martino, J. P. (1977). Technological Forecasting for Decisionmaking [in Russian]. Progress. (Original work published in 1972).

Migration Policy Institute. (n.d.). Immigrant and Emigrant Populations by Country of Origin and Destination [Interactive map]. Retrieved from https://www.migrationpolicy.org/programs/data-hub/charts/immigrant-andemigrant-populations-country-origin-and-destination

Miller, T. (2006). Demographic models for projections of social sector demand. Latin American and Caribbean Demographic Centre (CELADE) - Population Division. https://core.ac.uk/download/pdf/45621163.pdf

Ministry of Finance of Ukraine. (n.d.). https://www.minfin.gov.ua.

Pflaumer, P. (1988). Confidence intervals for population projections based on Monte Carlo methods. International Journal of Forecasting, 4(1), 135-142.

Ptoukha Institute for Demography and Social Studies of the National Academy of Sciences of Ukraine. (n.d.). https://www.idss.org.ua/index

Radchenko, I., O., \& Orlova, O. M. (Eds.). (2010). New thesaurus of modern Ukrainian language [in Ukrainian]. PP Holiaka V. M.

Shesternyak, M. M. (2019). Statistics in Ukraine: Main stages of development, status, trends and prospects [in Ukrainian]. Business Navigator. 4, 150157. http://www.business-navigator.ks.ua/journals/2019/53_2019/28.pdf

State Statistics Service of Ukraine. (n.d.). http://www.ukrstat.gov.ua.

Stoto, M. (1983). The accuracy of population projections. Journal of the American Statistical Association, 78(381), 13-20.

Tabeau, E., van den Berg Jeths, A., \& Heathcote, C. (Eds.). (2001). Forecasting mortality in developed countries: Insights from a statistical, demographic and epidemiological perspective (Vol. 9). Springer Science \& Business Media. https://link.springer.com/book/10.1007/0-306-47562-6\#about 
TSN. (2017, February, 1). Bloomberg named the countries most at risk of aging. Infographics [in Ukrainian]. https://tsn.ua/svit/starinnya-vdarit-po-rf-tabilorusi-ukrayina-blizka-do-mezhi-infografika-873468.html

Uriadovyi Kuriier. (2013, December 20). Forecast of the number and age of the population of Ukraine [in Ukrainian]. https://ukurier.gov.ua/uk/articles/ prognoz-chiselnosti-ta-vikovogo-skladu-naselennya

Vlasenko, N. S., Libanova, E. M., Makarova, O. V., Pyrozhkov, S. I. Pozniak, O. V., Stelmakh, L. M., Shvydka, H. Yu., \& Shevchuk, P. Ye. (2006). Comprehensive demographic forecast for Ukraine until 2050 (E. M. Libanova, Ed.) [in Ukrainian]. Ukrainskyi tsentr sotsialnykh reform.

Volska, O. M., \& Mykolaichuk, N. S. (2013). Information support as a tool for forecasting and planning the transition to sustainable development of the enterprise [in Ukrainian]. Economic Innovations, 54, 34-42.

Zakhozhai, V. B., \& Fedorchenko, V. S. (2006). Theory of statistics: textbook [in Ukrainian]. MAUP. 